\title{
Temperature dependant hydration kinetics of blanched and unblanched Amarnath (Rajgira) leaves
}

\author{
- Virendra Foke* and Dhananjay Kulkarni \\ Department of Agricultural Processing and Food Engineering, Shriram College of Agricultural Engineering, Paniv, Solapur (M.S.) \\ India \\ Email : virendrafoke@gmail.com; dhanukulkarni@gmail.com
}

*Author for Correspondence

Research chronicle : Received : 20.10.2018; Revised : 20.11.2018; Accepted : 23.11 .2018

SUMMARY:

A study was conducted to determine the effect of blanching on moisture adsorption and desorption characteristics of amaranth leaves by static gravimetric method. Different saturated salt solutions were prepared to provide constant relative humidity environments. Four amaranth leaves samples (Unblanched, Unblanched dried, Blanched and Blanched dried) were kept at 3 temperatures $\left(30^{\circ} \mathrm{C}\right.$, $40^{\circ} \mathrm{C}$ and $60^{\circ} \mathrm{C}$ ) with corresponding five relative humidity levels $(09.76$ to $90.28 \%)$. It was observed that EMC of leaves increased with increase in relative humidity at constant temperature also at constant ERH, EMC decreased with increase in temperature. The adsorption EMC was lower than the desorption EMC for all the samples at all temperature and relative humidity ranges. The blanched dried amaranth leaves exhibited lowest EMC than other samples. Sorption data was modeled by using Henderson equation to develop guideline for moisture sorption process. Both constant of equation found to be dependent on temperature. The relation between constant was expressed by a polynomial equation.

KEY WORDS : Temperature dependant, Hydration kinetics, Blanched, Unblanched Amarnath leaves

How to cite this paper : Foke, Virendra and Kulkarni, Dhananjay (2018). Temperature dependant hydration kinetics of blanched and unblanched Amarnath (Rajgira) leaves. Internat. J. Proc. \& Post Harvest Technol., 9 (2) : 44-48. DOI: 10.15740/HAS/IJPPHT/9.2/44-48. Copyright@ 2018: Hind Agri-Horticultural Society. 